cart before the horse-what ought to be done is to consider the market first and then the design of the organization to exploit it. This is something which the Select Committee on Science and Technology may take up when the Minister of Technology explains the proposals in the green paper next week.

\section{FAMILY PLANNING}

\section{The Pace of Bumbledom}

LOCAI health authorities in England and Wales are proving themselves shamefully slow in implementing the Family Planning Act of 1967. According to a survey by the Family Planning Association, only a quarter of the 204 authorities are providing the full facilities recommended by the act, and about 60 per cent are implementing the act only in part.

The intention of the act was that a family planning service including all methods of contraception should be provided for all who need it, regardless of their marital status. Unfortunately the responsibility for carrying out the act was left to local authorities, many of which are apparently more alarmed at being thought to provide "sex on the rates" than by the widespread sexual illiteracy in the British population and its consequences.

Many local health authorities restrict the provision. of services to certain categories; 36 authorities, for example, refuse to advise unmarried people on contracoptive methods. The borough of Bootle in Lancashire has distinguished itself by being the only local health authority in England and Wales to provide no services of any kind. Another 28 authorities are not implementing the act, but provide either premises or a general purpose grant for family planning activities.

Unless compulsory action is forced on the local health authorities, at the present rate of progress it will be another decade before the Family Planning Act is fully implemented and people in Britain have genuine access to modern contraceptive techniques. It is little wonder that "the vast majority" of women who apply for abortions, to quote a recent survey, "used no precautions at all or used unreliable methods" (Pare, C. M. B., and Raven, H., Lancet, i, 635; 1970). Docs everyone have to wait for Bootle?

\section{LENIN CENTENARY \\ Not Just Electrificution}

\section{from our Soviet Correspondent}

A SPECIAL session of the Academy of Sciences of the USSR was held last week in connexion with the forthcoming celebrations of the centenary of Lenin's birth (April 22). For many months the Soviet press has been filled with accounts of the contributions made by industry to this anniversary, as plans were fulfilled, factories completed, and new equipment installed, in a kind of technological Festschrift. Now, as the great date approaches, Soviet science at its highest level has met in jubilee session.

The opening speech of the session, by the Chairman of the Presidium of the Supreme Soviet, Nikolai V. Podgornyi, stressed the debt of the Soviet Union to science. In his reply, the President of the Academy of Sciences, Academician M. Keldysh, expatiated on the debt of Soviet science to Lenin. Such politenesses are traditional on these occasions, yet reading between the honorifics it is possible to distinguish what aspects of scientific progress the academy most wishes to stress on this jubilee occasion. Much emphasis was placed on the interconnexion between pure research and industrial applications, but once out of the field of industrialization and state planning, it seemed some. what difficult for the later achievements of the academy to be actively related to Lenin.

In honour of the occasion, Keldysh remarked on Lenin's interest in radio (called by Lenin "a gazette without paper and without distances") and attributed to it "the birth of new and most important trends of scientific and technical progress, including radar, semiconductor technology, radio electronics and systems of space communication and television". The Soviet space programme is attributed to Lenin's regard for the works of Tsiolkovskii, an interest which thus "gave to our country the possibility of accomplish. ing the most important step in the history of mankind-opening the era of space flight".

The speeches at the jubilee session of the academy tried to find explicit links between Lenin and scientific achievements. The Russian press, however, has made less attempt to find such specific linkages. For them, it seems sufficient to offer the achievements of the academy and its institutes as a tribute to the occasion. Thus a single issue of Pravda (March 31, 1970) associates with the jubilee not only such obvious topics as space flight, industrialization, computers and atomic power stations ("the first in the world"), but also the discovery of the Kursk magnetic anomaly, laser technology, radio astronomy and cosmic ray research. hydroacoustics, laser cybernetics, memory effects in thin films, high energy roactors and the use of solar power.

Scientific progress and Lenin are two topics which can always command good press coverage in the Soviet Union; in the jubilee session of the Academy of Sciences and the associated press articles, an exceptional opportunity has arisen for the two to be interwoven and combined.

\section{GEOPHYSICS}

\section{From Union to Colloquium}

THe ideas which were being aired last summer for a European Geophysical Union along the lines of the much-admired American Geophysical Union are now crystallizing into something more modest. At a meeting of geophysicists in Madrid last September, the formation of a European analogue of the AGU was discussed. to be called the European Geophysical Society, and British geophysicists were asked to take the initiative in organizing the first meeting (see Nature, 223, 1194: 1969). What seems to have happened since then is that in its passage through the committees of the Royal Society the notion of a European Geophysical Society has been muted to a European Geophysical Meeting and now a European Geophysical Colloquium. Colloquium sounds the wrong word when the target is an attendance of 500 or more, but the organizers are keen to stress the informality which they are aiming at.

The first planning meeting for the colloquium was held at the Royal Society on Wednesday last week, and attended by Professor S. K. Runcorn, the moving 